\title{
RELIGIOUSITY AND THEORY OF PLANNED BEHAVIOUR TOWARDS INTENTION TO GIVE INFAQ
}

\author{
Rifki Fajar Subekhi \\ Department of Syariah Economics, Faculty of Economics and Business \\ Universitas Airlangga \\ Email: rifki.fajar-13@feb.unair.ac.id \\ Ririn Tri Ratnasari \\ Department of Syariah Economics, Faculty of Economics and Business \\ Universitas Airlangga \\ Email: ririnsari@feb.unair.ac.id
}

\section{ARTICLE HISTORY \\ Received: \\ 12 December 2017 \\ Accepted: \\ 20 December 2017 \\ Online available: \\ 25 February 2018 \\ Keywords: \\ Religiosity, Theory of \\ Planned Behavior, Intention to Give Infaq}

Kata Kunci :

Religiusitas, Theory of

Planned Behavior,

Keinginan untuk

memberikan infaq

\section{ABSTRACT}

This study aims to determine the influence level of religiosity and Theory of Planned Behavior towards the intention to perform Infaq of traditional market Muslim traders. Data in this study is collected using questionnaires with sample research of 50 Muslim traders in the traditional market. Sampling techniques used are accidental sampling and purposive sampling. This research uses quantitative approach with multiple linear regression analysis. The results of this study indicate that religiosity level, behavior, Perceived Behavior Control, and subjective norms significantly influence the intention to perform infaq of traditional market Muslim traders. Suggestions for subsequent research are to increase the scope of research subjects to obtain more general information about related research, and to use other variables other than this research variable.

\section{ABSTRAK \\ Penelitian ini bertujuan untuk mengetahui} pengaruh tingkat religiusitas dan Teori Perilaku Terencana terhadap niat untuk melakukan Infaq pedagang pasar tradisional Muslim. Data dalam penelitian ini dikumpulkan dengan menggunakan kuesioner dengan penelitian sampel dari 50 pedagang Muslim di pasar tradisional. Teknik sampling yang digunakan adalah accidental sampling dan purposive sampling. Penelitian ini menggunakan pendekatan kuantitatif dengan analisis regresi linier 
berganda. Hasil penelitian ini menunjukkan bahwa tingkat religiusitas, perilaku, Perceived Behavior Control, dan norma subyektif berpengaruh signifikan terhadap niat melakukan infaq pasar tradisional pedagang muslim. Saran untuk penelitian selanjutnya adalah untuk meningkatkan cakupan subyek penelitian untuk mendapatkan informasi yang lebih umum mengenai penelitian terkait, dan untuk menggunakan variabel lain selain variabel penelitian ini.

\section{INTRODUCTION}

The presence of religion's doctrine influences someone's giving practices. Just like a trader. Madjid (1999) explains that a religious person should have 3 things known as religiosity concept. Furthermore, the presence of religion's doctrine will also affects certain individual behavior. One of the theories that explain about a person's behavior is Theory of Planned Behavior or planned behavior theory (Ajzen, 1991).

Surabaya's central bureau of statistics stated that there are 114 traditional markets that not included in PD Pasar Surya's supervision all over the town (tribunjatim.com). And the majority of the traders are Muslims. Qardhawi (1997) explains that one of the trading principals in Islam is preparing trader's stock for afterlife. It is better for a trader to realize that life on realm is only temporary. So a trader should also do giving practices when they trade. One of giving practices traders can do is Infaq. Infaq also can be implemented as a way to utter someone's gratitude over everything that has been gifted to them from Allah SWT. Based on the explanation above, religiosity rates, behavior, Perceived Behavior Control, and subjective norms should have an impact towards Infaq intentions of Muslim traders. As of the Infaq that has been discussed in this study, is an Infaq that people do regularly by giving the one in needs in form of money instrument whether it is intentionally or planned (Jen and Manfred 2006, on Muttawin, 2015).

\section{LITERATURE REVIEW}

\section{Infaq}

Infaq comes from the word anfaqa which means spend, spend, give or remove property. According to the term fiqh, the word infaq has the meaning of giving a portion of the possessed property to the person who has been hinted by the religion to give him such as faqir, poor, orphan, relatives and others (Mardany, 2012: 17). Meanwhile, according to Najmuddin et al (2006, in Priliyanti, 2010) Infaq means to remove some of the wealth or income for the interests of the ordered teachings of Islam. Infaq issued by everyone who believes, both high and low income, both fieldy and narrow. 


\section{Infaq as A Islamic's Filanthrophy}

The term philanthropy comes from Greek, Philos (Love) and anthropos (human). Literally, philanthropy is the conceptualist of voluntary practice of giving, ministry, and association to assist others in need as an expression of love. So philanthropy can be defined as a voluntary act for the public interest. In the reality of life, the philanthropy aspect is closely related to the equitable distribution of wealth that distinguishes between the poor and the rich (Chaider and Irfan, 2005). Linge (2015) describes philanthropy as an alternative for a community group to reduce social inequality among the community.

\section{Religiousity}

Widiyanta (2005:80) said that religion is a duty or rule of rules to be performed, all of which serve to bind and establish a person or a group of people in relation to God or fellow human beings, as well as nature sekitatnya. Suhardyanto (2001) describes religiosity as a personal relationship with the divine, omnipotent and omnipotent person (God) who considers the desire to please the divine person by carrying out his will and away from the unwanted (the prohibition).

According to Glock \& Stark (1994), in Ancok and Suroso (1994) explains there are five dimensions of a person's religiousness that can be measured to know whether a person is religious or not, such as:

1. Confidence Dimension (Aqidah)

This dimension explains the degree to which a person accepts dogmatism in religion (Ratnasari et al., 2015).

2. The Dimensions of Religious Practice (Sharia)

The dimensions of religious practice show the level of frequency or intensity of people when performing ritual activities as instructed and encouraged by their religion (Ratnasari et al., 2015).

3. Dimension of Experience (Ihsan)

The density of experience is the religious experience encountered by a Muslim while living his religious teachings (Ratnasari et al., 2015).

4. The Dimension of Religious Knowledge (Science)

The dimension of religious knowledge Is the extent to which a person understands the teachings of his religion (Ratnasari et al., 2015).

5. Dimension of Applying (Akhlak)

The dimension of practice is the degree to which a person's behavior is based on his religious teachings in his life (Ratnasari et al., 2015).

\section{Attitude}


Ajzen (2005) also explains that attitudes are defined as dispositions or tendencies to respond to things that are evaluative, liked, or disliked for objects, people, institutions, or events. Osman et al (2015) affirmed the more positive the individual attitude, the higher the individual's intentions. Attitude is closely related to a decision to behave. the attitude of a Muslim to a behavior of course has its own process and principle. The decision-making process of a Muslim begins with an introduction to the problem, which is then followed by information retrieval, and an alternative evaluation. The part of the alternative evaluation consists of the denial of kemudharatan, the perception of Islamic needs, as well as the perception of mardhatillah or pleasure of Allah SWT. Which then from this process can lead to a decision to perform a behavior or not.

\section{Perceived Behaviour Control}

Ajzen (1991) Perceived Behavior Control or behavior control that is perceived as a feeling of one's ability to show the desired behavior. The perceived behavior control refers to people's perceptions of their ability to perform certain behaviors (Osman et al, 2015).

Ajzen (1985) asserted that with individual behavior controls believing how easy or difficult it is to perform a particular behavior. Perceived Behavior Control can indirectly affect behavior, through intent so that Perceived Behavior Control can be used to predict behavior directly.

\section{Subjective Norms}

Ajzen (1991) explains that subjective norms are social pressures felt by an individual to do or not to do an act. Cruzz et al (2015) explains that subjective norms are individual beliefs to obey the direction or suggestions of people around them to participate in the move. Ramayah and Aaron (2005, in Cruzz et al., 2015) describe some who can influence subjective norms including family support, support from important people, and peer support. Mazocchi (2008) states that subjective norms are the result of normative beliefs, which are the manifestations of:

1. Strength of the belief, the strength of belief in the views of the relevant to a behavior.

2. Motivation to comply, that is motivation to meet the expectations of relevant circles.

\section{Behavioral Intention}

Ajzen (1991) states that the formation of intentions is influenced by several factors such as attitudes, subjective norms, and behavior control. According to Spears and Singh in (Fatimah and Ratnasari, 2015) the intention of behaving is a person's tendency to behave erdasarkan feeling, experience, or evaluation of previous experiences.

\section{Relationship between Religiousity and Intention to Give Infaq}


Duraseh (2010) Explains that religion as a system in addition to issues of religious emotion, the impact of religion on a person that is important in the outcome, as in Islam which always teaches the value of virtue, so that a solemn or highly religious person will have the pattern of behavior that animates the value of humanity because Islam always teaches the value of virtue. Based on the above statement, it can be concluded that religiosity can affect the behavior of a person's charity, as well as the intention to give infaq. Given the infaq is one form of worship is very recommended by Allah SWT to create prosperity on earth, and to achieve blessings in the world and the hereafter.

\section{Relationship between Attitude and Intention to Give Infaq}

Ajzen (1991) describes attitude is one's view to support or reject against a behavior, if someone more supportive of a behavior then his intention to perform a behavior will be higher. In other words, attitude is a process of judgment of a person to a behavior that creates a person's readiness to perform a behavior that raises the intention to perform a behavior. So if a Muslim trader has an increasingly positive assessment of berinfaq behavior, then the higher the intention of individuals to gve infaq.

\section{Relationship between Perceived Behaviour Control and Intention to Give Infaq}

Perceived Behavior Control that shows a person's view of his ability to perform a behavior. Ajzen (1991) explains the intention to behave can only be realized if the behavior is still within the reach of personal ability. Actualization of behavior in a given capacity still depends on non-motivational factors such as the availability of opportunities and resources (eg time, money, ability, help of others) (Ajzen 1991). So Muslim individuals have the resources and opportunities are good, they should utilize the ability to the good things according to the Islamic Shari'ah one of them is berinfaq. Thus, it can be deduced that when a Muslim trader feels having the ability to give infaq then the higher the intention to give infaq.

\section{Relationship between Subjective Norms and Intention to Give Infaq}

Tan (2000, in Cruzz et al., (2015) is a social influences that affect a person's behavior. A person will have the desire to an object or behavior if he was influenced by the people around him to do it or he believes that the environment or the people around him support for what will be done and some parties that can influence an individual in behaving include family, people who are considered important, and friends who have certain characteristics Similarly, if the subjective norm more supportive of a behavior, the intention of someone to perform a behavior will (Ajzen, 1991) From the above explanation, it can be concluded when a Muslim trader gets support from the people closest like family, people who are considered important, and fellow traders to 
perform berinfaq behavior, it will be stronger also intention a trader of Muslim traditional market to fulfill infaq.

\section{RESEARCH METHOD}

Data in this study is collected using questionnaires with sample research of 50 Muslim traders in the traditional market. Sampling techniques used are accidental sampling and purposive sampling. This research uses quantitative approach with multiple linear regression analysis. Sample used on this study is Muslim traders Tandes district of Surabaya City's traditional market. Technique used is non propability sampling, because the amount of Muslim traders in one traditional market cannot be determined. Total Sample used in this study is 50 respondents. Data collection was done using documentation and questionnaire. Data quality test using validity test and reliability test. Data analysis technique (Ghozali, 2009) : 1) Classic assumption test; 2) multicollinearity; 3) normality test; 4) heterokesdastisity test; 5) double linear regression; and 6) coefficient determinants (R2).

\section{RESULT AND DISCUSSION}

Table 1

Multiple Regression Analysis

\begin{tabular}{|l|r|r|r|r|r|}
\hline \multirow{2}{*}{ Model } & \multicolumn{2}{|c|}{} & \multicolumn{1}{c|}{$\begin{array}{c}\text { Standardized } \\
\text { Coefficients }\end{array}$} & \multirow{2}{*}{ Sig. } & \\
\cline { 2 - 5 } & \multicolumn{1}{|c|}{ B } & Std. Error & \multicolumn{1}{c|}{ Beta } & & \\
\hline (Constant) & -.946 & .337 & & -2.809 & .007 \\
Religiusitas & .375 & .176 & .266 & 2.128 & .039 \\
1 Sikap & .276 & .114 & .254 & 2.420 & .020 \\
PBC & .292 & .103 & .242 & 2.821 & .007 \\
Norma Subyektif & .314 & .092 & .323 & 3.413 & .001 \\
\hline
\end{tabular}

$$
Y=(-0,946)+0,375 \times 1+0,276 \times 2+0,292 \times 3+0,314 \times 4
$$

$Y=$ Infaq Intentions

$\mathrm{X} 1$ = Religiosity

$X_{2}=$ Behavior

$\mathrm{X} 3=$ Perceived Behaviour Control

X4 = Subjective norm 
Table 2

Determination Coefficient

\begin{tabular}{|c|}
\hline Koefisien Determinasi $\left(\mathrm{R}^{2}\right)$ \\
\hline 0.821 \\
\hline
\end{tabular}

Based on the table above, coefficients determinant ( $\mathrm{R}$ Square) can be interpreted that $82,1 \%$ of the infaq intentions $(\mathrm{Y})$ on regression model can be explained by religiosity as an independent variable (X1), behavior (X2). Perceived behavior control (X3), and subjective norm (X4). While there $17,9 \%$ affected by other variable that used in this study.

Hyphotesis Test

Table 3

Simultaneous Significance Test (F test)

\begin{tabular}{cc}
\hline Nilai F & Sig \\
\hline 51.481 & $0.000^{\mathrm{b}}$ \\
\hline
\end{tabular}

Based on the table above, the result of F-count is 51,481 with significance value $0.000<0.05$. It concludes that there's a stimulant effect between religiosity rate, behavior, perceived behavior control, and subjective norm towards Muslim trader's infaq intentions on traditional market.

Table 4

Individual Parameter Significance Test (t Test)

Variabel Nilai $t \quad$ Sig.

\begin{tabular}{ccc}
\hline (Constant) & - & \\
& & .007 \\
\hline Religiusitas & 2.809 & \\
\hline & & .039 \\
\hline Sikap & 2.128 & \\
\hline & & .020 \\
\hline PBC & 2.420 & .007 \\
\hline Norma & 2.821 & \\
\hline & & .001 \\
\hline Subyektif & 3.413 & \\
\hline
\end{tabular}


Based on the table above, the result of significance from each variable is smaller than 0.05 , which means that variables in this study affects partially and positively towards Muslim trader's infaq's intentions.

\section{Effect of Religiosity level towards Muslim trader's infaq intentions in traditional market.}

The result of this study shows the significance level of religiosity got the $0,039<0,05$ score. This concludes that religiosity rate positively and significantly affects Muslim trader's infaq intentions. This fact also support previous studies that explain one of mashlahah (satisfaction) rate indication for religious people affected by total amount of expenses for religious activities, whether the one that give realm benefit, or afterlife benefit. In the study, the religiosity level of the respondents significantly affects expenses spent for religious purpose. Someone with high religiosity, allocate their earnings more for religious purpose like zakat fitrah, zakat maal, infaq, and shodaqoh. So it could be concluded that the higher the religiosity rate, the higher someone's intentions to give in order to be safe in dunia and akhirat.

\section{Effect of behavior towards muslim traders infaq intentions in traditional market.}

The result of this study explains that behavior affects significantly and positively towards muslim trader's in traditional market infaq's intention. Based on this result, variable significamce level of behavior got $0,020<0,05$. It concludes that behavior positively and significantly affects muslim trader's in traditional market infaq's intention. Generally, respondents see that they can feel the benefit from doing infaq, like having more accepting hearts, easier flow of fortune, make fortune more blessed, and being a more giving person.

This study supported by the statement from Osman and friends (2015) who said that the more positive someone's behavior, the bigger someone's intentions toward a certain behavior. In other words, behavior affects intentions because supportive view is a believe that if someone do something good, then they will also got something good in return, in this case, intentions to do infaq.

\section{Effect of perceived behavior control towards muslim traders infaq intentions in traditional market.}

The result of this study explains that perceived behavior control affects significantly and positively towards Muslim traders in traditional market infaq's intention. Based on this result, variable significance level of perceived behavior control got $0.007<0.05$. It concludes that perceived behavior control positively and significantly towards trader's infaq intentions in traditional market.

Generally, besides giving them rewards, doing infaq also can help others in need, whether on a public facility form like masjid, or for a personal needs. Some respondents 
also explains that there's no reason for someone to not doing infaq, because fortunes that Allah gave you has been enough and guaranteed by Allah SWT, and infaq can be done anywhere.

\section{Effect of subjective norms control towards muslim traders infaq intentions in traditional market.}

Subjective norm in this study known of having significance effects on traders infaq intentions. Based on the result, subjective norms level of significance got $0.001<0.05$ score. This concludes that subjective norms significantly affect trader's infaq intentions.

Generally, respondents explain that there's a social drive towards respondents to do infaq, especially from family. Because of economic condition that has been fulfilled, so it is only understandable if they give part of their fortunes for infaq in order to get more blessings.

\section{CONCLUSION}

Based on the result in field, muslim traders in traditional market tend to have high level of religiosity. Primarily based on prayer implementation, either sunnah or compulsory prayer and behaving appropriately based on syariat Islam, not just fulfilling responsibility as a muslim. But having a chance to pray and muamalah or behaving based on syariat islam is a need that really useful as a muslim because it is a way for a muslim to interract with Allah SWT with hopes such as survive in dunya and akhirat. The result of this study signifies that when a muslim trader in tradirional market have a high level of religiosity then they will also have a high tendency to give infaq. The effect of religiosity rate, behavior, perceived behavior control, and subjective norms overall positively and significantly affects muslim trader's intention to give infaq in traditional market.

\section{REFERENCES}

Ajzen. (1991). The Theory of Planned Behavior" Organizational Behavior and Human Decission Processes. Vol.50 No.2, PP179-211

,(2005).Attitudes, Personality and Behavior.2nd Edition. Open University Press, New York. N.Y 
Religiousity And Theory Of Planned ...

Ancok, Djamaludin dan Suroso. (1994). Psikologi Islami. Solusi Islam Atas Problemaproblema Psikologi. Solusi Islam Atas Problema-problema Psikologi. Yogyakarta : Pustaka Pelajar

Aravik, Havis. (2016). Ekonomi Islam, Konsep, Teori, dan Aplikasi serta Pandangan Pemikir Ekonomi Islam. Malang: Penerbit Empatdua

Arikunto, Suharsini. (2013). Prosedur Penelitian : Suatu Pendekatan Praktik. Jakarta : PT Asdi Mahasatya

Ghozali, Imam. (2009). Metode Penelitian, Semarang : Badan Penerbit Universitas Diponegoro

Madjid, Nur Cholid. (1999). Islam Doktrin dan Peradaban. Jakarta : Paramadina

Muttaqin, Zein. (2015). Analisis Pengaruh Pendapatan Terhadap Jumlah Infaq Peserta Pengajian Rohani. Jurnal Ekonomi dan Hukum Islam, Vol.5, No.2

Osman. Faiz Amirul. (2014). An Analysis of Cash Waqf participation Among Young Intellectuals. International Academic Conference, Istanbul. 2014

Qardhawi, Yusuf. (1997). Norma dan Etika Ekonomi Islam. Jakarta : Gema Insani Press

Ratnasari, Ririn Tri. (20120. Manajemen Pemasaran Islam. Modul 3. Surabaya: Departemen Ekonomi Syariah Fakultas ekonomi dan Bisnis Universitas Airlangga -.(2015). Religiousity on Shopping Orientation and Behavioral Intention For Moslem and Non-Moslem Costumers. 6th Global Islamic Marketing Conference. www.E-Journal.unair.ac.id.

Savitry, Qory. (2015). Pengaruh Sikap, Norma Subyektif, Preceived Behavior Control, Pengalaman Menyumbang, dan Faktor Demografis Terhadap Intensi Menyumbang. Skripsi diterbitkan. Universitas Islam Negeri Syarif Hidayatullah Jakarta

Qardhawi, Yusuf. (1997). Norma dan Etika Ekonomi Islam. Jakarta: Gema Insani Pres 